\title{
Linear and non-linear effects of goldenrod invasions on native pollinator and plant populations
}

\author{
Dawid Moroń (1) P Piotr Skórka • Magdalena Lenda • Joanna Kajzer-Bonk • \\ Lukasz Mielczarek • Elżbieta Rożej-Pabijan • Marta Wantuch
}

Received: 28 August 2017/ Accepted: 7 November 2018/Published online: 19 November 2018

(C) The Author(s) 2018

\begin{abstract}
The increased introduction of non-native species to habitats is a characteristic of globalisation. The impact of invading species on communities may be either linearly or non-linearly related to the invaders' abundance in a habitat. However, non-linear relationships with a threshold point at which the community can no longer tolerate the invasive species without loss of ecosystem functions remains poorly studied. We selected 31 wet meadow sites that encompassed the entire coverage spectrum of invasive goldenrods, and surveyed the abundance and diversity of pollinating insects (bees, butterflies and hover flies)
\end{abstract}

D. Moroń $(\bowtie)$

Institute of Systematics and Evolution of Animals, Polish

Academy of Sciences, Sławkowska 17, 31-016 Kraków,

Poland

e-mail: dawidmoron@poczta.onet.pl

P. Skórka

Institute of Nature Conservation, Polish Academy of

Sciences, Mickiewicza 33, 31-120 Kraków, Poland

e-mail: skorasp@poczta.onet.pl

M. Lenda

School of Biological Sciences, The University of

Queensland, Qld 4072 Brisbane, Australia

e-mail: m.lenda@uq.edu.au

J. Kajzer-Bonk

Institute of Zoology and Biomedical Research,

Jagiellonian University, Gronostajowa 9, 30-387 Kraków,

Poland

e-mail: joanna.kajzer.bonk@gmail.com and native plants. The species richness of native plants decreased linearly with goldenrod cover, whereas the abundance and species richness of bees and butterflies decreased non-linearly with increasing goldenrod cover. However, no statistically significant changes across goldenrod cover were noted for the abundance and species richness of hover flies. Because of the nonlinear response, goldenrod had no visible impact on bees and butterflies until it reached cover in a habitat of about $50 \%$ and $30-40 \%$, respectively. Moreover, changes driven by goldenrod in the plant and

\author{
Ł. Mielczarek \\ Department of Forests and Nature, Kraków Municipal \\ Greenspace Authority, Reymonta 20, 30-059 Kraków, \\ Poland \\ e-mail: lukasz@insects.pl \\ E. Rożej-Pabijan \\ Institute of Biology, Pedagogical University, \\ Podchorążych 2, 30-084 Kraków, Poland \\ e-mail: elarozej@vp.pl \\ M. Wantuch \\ Institute of Environmental Sciences, Jagiellonian \\ University, Gronostajowa 7, 30-387 Kraków, Poland \\ e-mail: swistakmw@o2.pl
}


pollinator communities were related to species loss rather than species replacement. We demonstrated that the impact of goldenrod cover on a habitat is not instantaneous. Habit management aimed at preventing the invasion process and alleviating its impact should take into account that, for the non-linear relationships, the negative impact can appear rapidly after crossing the threshold point.

Keywords Bees - Biodiversity - Biological conservation - Butterflies - Ecological invasions · Hover flies · Invasive plants

\section{Introduction}

The introduction of non-native species to habitats increases consistently as a result of globalisation (Amano et al. 2016). Established alien organisms-invasive species-cause environmental changes that threaten native biodiversity and the human economy (Pejchar and Mooney 2009). The environmental changes induced by invasive species concerns the composition of invaded communities (Moroń et al. 2009). The effects may move through food webs to influence other trophic levels and different habitats (Simao et al. 2010; Lenda et al. 2018). In particular, the loss of plant species, primary producers, may impact key ecological processes such as ecosystem productivity (Pyšek et al. 2012), decomposition (van der Putten et al. 2013), or ecosystem resilience to disturbances (Richardson et al. 2007). As a result, the diversity decline at the level of the primary producers may impact associated arthropod species (Haddad et al. 2009). However, whether plants and arthropod communities change at all points along the invasion pathway (i.e. a linear response to invasion), or if there is rather a threshold beyond which the communities change as the invasive plant becomes dominant (non-linear response to invasion), remains unclear.

It is frequently assumed that the impact of an invading species is proportional (linearly related) to its density or abundance in a habitat (Yokomizo et al. 2009; Elgersma and Ehrenfeld 2011; Panetta and Gooden 2017). However, one may hypothesise that the density-dependent impact of invader populations may also elicit a non-linear response from native species (Crooks 2005; Panetta and Gooden 2017). Thus, there might be a threshold of density of invasive alien species at which negative effects on native communities appear (Fig. 1). It is expected that, if the threshold of density is high (Fig. 1), the number of species effectively endangered during the course of invasion tends to be underestimated and hence the consequences of invasions on biodiversity might be undervalued.

This study explores the pattern of the densitydependent impact of invaders using pollinating arthropods. Pollinators are key components of ecosystems providing various ecosystem services important for agriculture and the human economy (Mouquet et al. 2012). The effect of invasive plants on a pollinator community is rather equivocal (Bjerknes et al. 2007). The invasion of alien plants might affect pollinator populations by decreasing the diversity of native plants, and subsequently the pollinator food-base (Moroń et al. 2009). At the same time, alien flowering crops might boost pollinator population sizes by increasing their resource availability (Tepedino et al. 2008). Thus, a non-linear impact of invaders on native pollinators may be caused by the buffering characteristics of the environment (McCary et al. 2016). For example, plant-pollinator food webs may exhibit high functional redundancy (Memmott et al. 2006). Thus, even though an invasive plant at lower densities may eliminate several native plant species, high functional redundancy of the food web reduces the probability that this will lead to a decline in pollinators. Moreover, a novel invader might not substantially reduce foraging options for arthropods (McCary et al. 2016). Less food-specialised pollinators may be able to find their preferred resource while ignoring the presence of the plant invader, resulting in zero or minimal changes to a pollinator community in response to plant invasions at low densities. Additionally, the non-linear impact of invasive species can be generated by the neutral or partially positive effects of invaders on natives (Hejda and Pyšek 2006; Hulme et al. 2012), for example if an invader constitutes a novel, collateral food-source at low abundance and density (Salisbury et al. 2015). Regardless of the direction of the invasive species impact on pollinators, a full understanding will require knowing whether this impact may be linear or nonlinear as the invader becomes more abundant.

As a model invasive alien plant we used North American goldenrods (Solidago canadensis and $S$. gigantea), among the most invasive species in Europe and Asia (Weber 2001). Flowers of this species are 
Fig. 1 Conceptual model of density-dependent impact of invasive species on native communities. With the increasing density of an invasive species, the richness of native communities decreases. Decrease of native communities could be nonlinear (community 1 and 2) or linear (community 3 ) dependent on the invaders' density. Arrows at the top indicate the threshold points for community 1 and 2

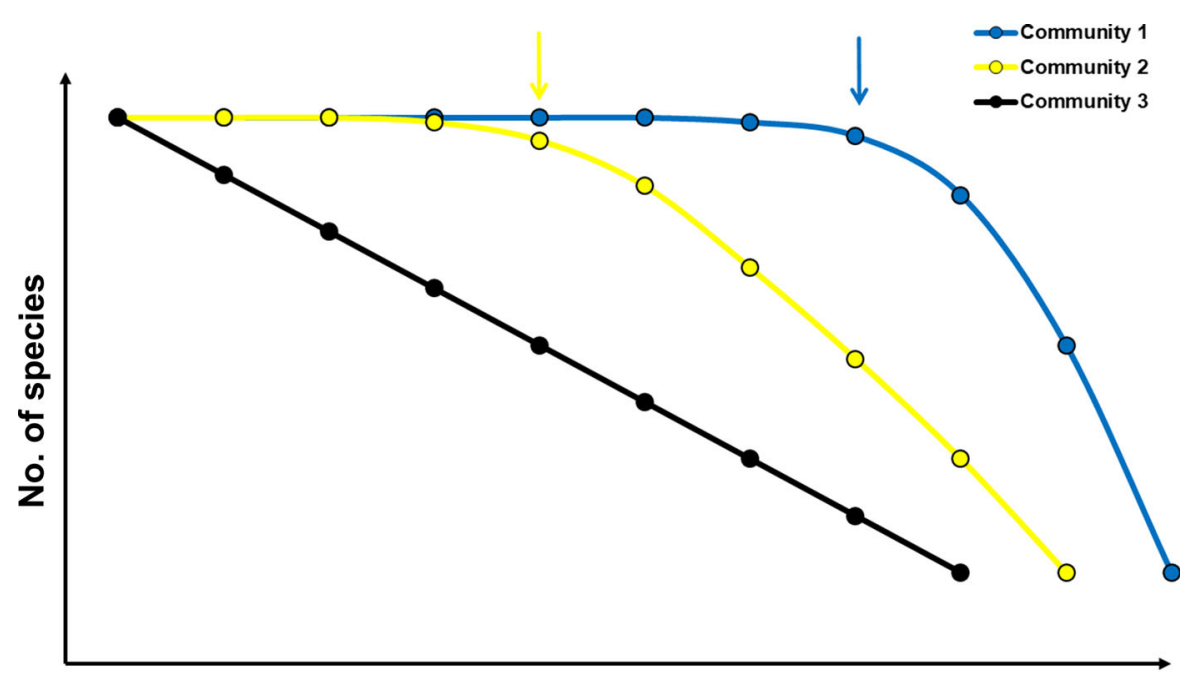

Invader density

rich in pollen and nectar (Kabuce 2006), and are visited by a spectrum of pollinating insects in their native areas (Pavek 2012) and in invaded ones (Kabuce 2006). Earlier findings showed that, in meadow habitats invaded by non-native goldenrods, there is a significant decline of native plant diversity (Moroń et al. 2009; Pal et al. 2015). The goldenrod invasions also cause communities of native pollinators (Moroń et al. 2009; Fenesi et al. 2015), ants (Lenda et al. 2013; Kajzer-Bonk et al. 2016), beetles (de Groot et al. 2007; Baranová et al. 2014) or birds (Skórka et al. 2010) to disappear.

We selected sites ranging from 0 to $100 \%$ of invasive goldenrod cover, and surveyed the abundance and diversity of the most important pollinator communities of the temperate zone (bees, butterflies and hover flies). For better mechanistic understanding of the potential linear or non-linear pollinators' response to the invasive goldenrods, we also recorded the number of native plant species, which are the main resources for pollinators (Blaauw and Isaacs 2014). We expected that there would be a non-linear response of pollinator communities to increasing goldenrod cover. We identified threshold values at which the negative impact increases for different groups of pollinators. Moreover, we tested whether the response of plant and pollinator assemblages reflects the degree of goldenrod cover. Specifically, we address the following questions: (1) Is there evidence of nonlinearity in the numerical response of native plants and pollinators as the cover of goldenrod increases? (2) If so, what is the threshold goldenrod cover at which the native plants and pollinators start to show a decrease in abundance and species richness? And, (3) Are plant and pollinator community changes caused by species replacement (i.e., turnover) or elimination (i.e., nestedness) as goldenrod cover increases?

\section{Materials and methods}

Study area

The study was carried out in the meadow landscape located in the valley of the Vistula river near the city of Kraków, southern Poland (Fig. 2). Using present and historical vegetation data, we mapped the meadows (Kornaś and Medwecka-Kornaś 1974; Dubiel 1995; Pepkowska 2002; Skórka et al. 2007; Moroń et al. 2009) where soil is periodically saturated with water. The meadows have similar geological history, climate and soil properties (Kornaś and Medwecka-Kornaś 1974). All the studied meadows originated from wet meadows dominated by Molinia caerulea, Galium boreale and Sanguisorba officinalis with a number of other plants suitable for pollinators (Kornaś and Medwecka-Kornaś 1974; Moroń et al. 2008). After the collapse of communism, the wet meadows were maintained mostly by an irregular management scheme, with intervals of several years between mowing, burning or grazing (Skórka et al. 2007).

The rapid change in management allowed the goldenrod invasion (S. canadensis and S. gigantea) to begin at all sites basically at the same time, 20 years 
Fig. 2 Location of 31 study sites in the Krakow region, Southern Poland

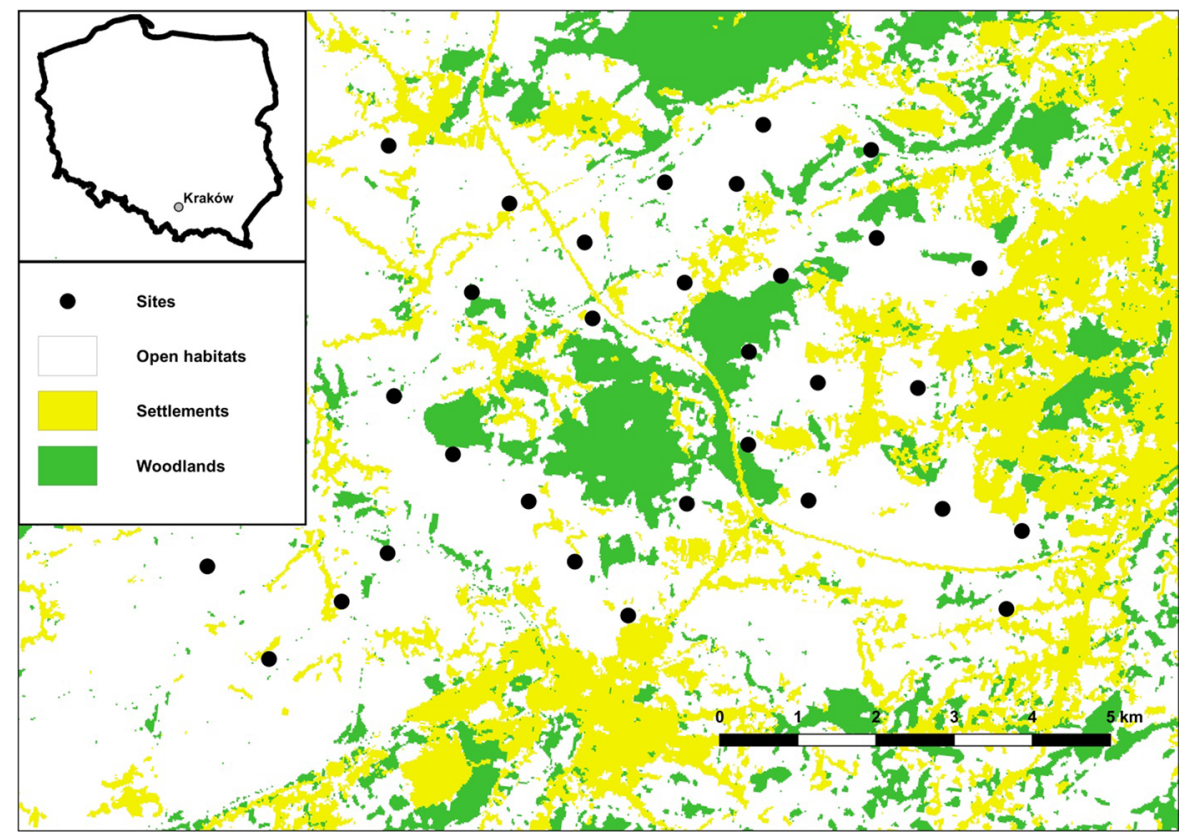

before this study began (which was confirmed by historical vegetation data). Differences in invasive goldenrod cover appear to be the result of local, random factors occurring at sites, e.g. occasional mowing, grazing or burning (personal observations). Moreover, because goldenrods are herbaceous plants, we can assume that the impact of coverage is not dependent on the temporal component of their lifecycle development stages (time taken for development from seedling to mature plant), unlike, for example, the case for trees (Pawson et al. 2010). From all located meadows, we selected 31 patches, ensuring that invasive goldenrod cover ranged from $0 \%$ up to $100 \%$ (43.06 $\pm 35.32 \%$; mean $\pm \mathrm{SD})$. To calculate goldenrod cover, the study sites were carefully inspected and all patches of invasive goldenrods were mapped with the help of GPS. The study sites were at least $1.07 \pm 0.18 \mathrm{~km}$ apart and were surrounded by arable fields, forests and human settlements.

To control for the confounding effects of potential spatial gradients (sites' size and distance to arable fields, human settlements, meadows and woodlands) for the investigated impact of goldenrod cover on pollinators, the wet meadows were selected in a relatively homogenous landscape. However, we applied QGIS 2.18.14 (QGIS Development Team 2018) software to calculate the spatial gradients of the study sites and used Spearman's test to ensure that the characteristics did not correlate with goldenrod cover. The sizes of the sites $(6.12 \pm 6.48 \mathrm{ha})$ were not correlated with goldenrod cover $\left(r_{S}=0.136\right.$, $p=0.274)$. The goldenrod cover of selected sites did not correlate with the sites' distance to the closest arable field $\left(\mathrm{r}_{\mathrm{S}}=0.167, p=0.369 ; 473 \pm 516 \mathrm{~m}\right)$, woodland $\left(\mathrm{r}_{\mathrm{S}}=-0.277, p=0.132 ; 259 \pm 294 \mathrm{~m}\right)$, human settlements $\quad\left(\mathrm{r}_{\mathrm{S}}=0.175, \quad p=0.347\right.$; $239 \pm 168 \mathrm{~m})$ or meadows $\left(\mathrm{r}_{\mathrm{S}}=0.082, p=0.660\right.$; $125 \pm 69 \mathrm{~m})$.

\section{Surveys}

A $200 \mathrm{~m}$ transect was established in the middle of each site (Fig. 2; Pollard and Yates 1993; Westphal et al. 2008). Bees and hover flies were sweep-netted along the transect on each site during four surveys, first in June, second in July, third in August and fourth in September (overall 124 transect-walks). During the transect walks on each site, the collectors walked slowly, making 500 sweeps to standardise the sweeping effort. Sweeps encompassed all flowering plants at transects. Butterflies were counted on each transect, on four occasions from June to September of 2010, and were captured only for identification purposes. The duration of a single transect walk for butterfly assessment lasted $20 \mathrm{~min}$. The order in which the transects were sampled was random. Each transect 
was visited during different parts of the day (9:00 a.m. to 6.00 p.m.) throughout the season to cover entire period of pollinator activity during a day. The native plants were surveyed at five permanent plots (each with an area of $3.14 \mathrm{~m}^{2}$ ), distributed at each transect with a distance of $50 \mathrm{~m}$ between the plots. The number of native plant species was surveyed twice during the study: first in the pre-blooming period (beginning of May) and second at the beginning of the goldenrod flowering period (in the middle of July).

\section{Statistical analysis}

To study the relationship between goldenrod cover and its impact on meadow pollinating insects and the potential role of native plant richness in shaping the effect, we used generalised additive mixed models (GAMM) with Poisson error and a logarithmic link function. Applying additive models, we analysed the expected non-linear relationships between the response and the explanatory variable (Wood 2006). We employed separate models to check whether the per site species richness and abundance of bees, butterflies and hover flies, and the richness of plant species, depended on goldenrod cover (seven models overall). Because the effect of the goldenrod cover on pollinators was consistent across the pre-flowering and flowering periods ("Appendix 1"), and as the effect on native plants was not dependent on whether plants were forbs or graminoids ("Appendix 2"), we pooled the data for each group (bees, butterflies, hover flies and plants). We fitted the goldenrod cover with the help of splines, to allow for the possible non-linear relationship between the variables and the cover. The possible spatial dependence of the data was addressed by including the interaction of longitude and latitude in GAMMs fitted with thin plate regression splines (Wood 2006). Using this procedure, part of the variation of a response variable is explained by the spatial location of a given transect, which makes the residuals from GAMMs spatially independent (Wood 2006). We based the parameter estimation on the "mgcv" (Wood 2006) computing models implemented in R (R Development Core Team 2016).

Moreover, to identify a threshold value of goldenrod cover where the slope of function described its impact on pollinators and plant changes we used estimation of regression models with break-points. The break-point values were calculated for all significant non-linear relationships revealed by GAMMs. To this point we applied the R (R Development Core Team 2016) package "segmented" (Muggeo 2015).

Differences between species assemblages can be an effect of species replacement between sites (turnover, which leads to different assemblages) and species loss from site to site (nestedness, which leads to the poorest assemblage being a strict subset of the richest one, Baselga and Orme 2012). To understand the mechanism of potential effects of goldenrod cover on pollinator and plant assemblages, we used the Jaccard dissimilarity index. This index takes into account the species that are different between a pair of sites, and is defined as the proportion of the overall pool of species present at each site. The index ranges from 0 for identical pool of species at all sites to 1 for no common species between sites. The dissimilarity indexes were computed for each pair of sites for pollinators and plants, and the total dissimilarity partitioned into two separate components accounting for the dissimilarity derived solely from turnover and that derived from nestedness (Baselga 2012). Then, with the help of partial redundancy analysis, we tested the goldenrod cover contribution to the dissimilarity derived from turnover and nestedness of pollinators and plants. The statistical analysis was performed using the packages "betapart" (Baselga et al. 2013) and "vegan" (Oskanen et al. 2013), implemented in R ( $R$ Development Core Team 2016).

\section{Results}

Overall, 79 native plant and 135 native pollinator species were recorded in the investigated plots (Table 1; "Appendix 3"). Among the bees, the most abundant were Bombus lapidarius (17\% of the total number of bees), B. terrestris (17\%) and Seladonia subaurata (11\%; “Appendix 3"). Three species made up $36 \%$ of the total number of butterflies: Aphantopus hyperantus (13\% of the total number of butterflies), Pieris rapae (13\%) and Coenonympha pamphilus (10\%; "Appendix 3"). The most abundant species of hover fly were Sphaerophoria scripta (28\% of the total number of hover flies), Melanostoma mellinum (19\%) and Eristalis arbustorum (7\%; “Appendix 3”).

Linear and non-linear responses of plant and pollinator communities were found. The number of 
Table 1 The number of collected species and individuals from each pollinator group

\begin{tabular}{llc}
\hline Pollinator group & No. of species & No. of individuals \\
\hline Bees & 40 & 247 \\
Butterflies & 53 & 2258 \\
Hover flies & 42 & 468 \\
\hline
\end{tabular}

native plant species decreases linearly with increasing goldenrod cover (Fig. 3a; Table 2), whereas the he abundance and species richness of hover flies did not change across goldenrod cover (Fig. 3b, c, Table 2). However, the abundance of bees and their species richness decreased non-linearly with increasing goldenrod cover (Fig. 3d, e; Table 2). As with bees, a nonlinear decrease in abundance and species richness of butterflies occurred towards high goldenrod cover (Fig. 3f, g, Table 2).

Threshold points were identified for non-linear responses of pollinators to goldenrod invasion. There was a negative effect of invasive goldenrods on bee species, and the number of individuals appeared at cover $( \pm \mathrm{SE})$ of $50 \pm 2 \%$ and $49 \pm 1 \%$, respectively (Fig. 3). A comparable detrimental impact of goldenrods on butterfly abundance appeared at cover of $31 \pm 14 \%$ (Fig. 3). For the richness of butterfly species, the relationship, albeit non-linear, was more monotonic, with a threshold point at $43 \pm 12 \%$, (Fig. 3).

Species assemblages derived from species replacement (turnover) did not differ between sites of different goldenrod cover for all pollinator groups and plants. However, species assemblages derived from species loss (nestedness) was significantly different between sites of different goldenrod cover for bees $\left(\mathrm{F}_{1,29}=28.53, \mathrm{R}^{2}=0.50, p=0.002\right)$, butterflies $\left(\mathrm{F}_{1,29}=41.53, \mathrm{R}^{2}=0.52, p=0.001\right)$ and plants $\left(\mathrm{F}_{1,29}=28.15, \mathrm{R}^{2}=0.49, p=0.001\right)$ but not for hover flies $\left(\mathrm{F}_{1,29}=1.21, \mathrm{R}^{2}=0.03, p=0.416\right)$.

\section{Discussion}

An underlying assumption of the impact of invasive species on native ones is the proportional negative relationship between invader density and native population sizes (Dupont et al. 2009; Elgersma and
Ehrenfeld 2011; Panetta and Gooden 2017). Such a linear relationship is more expected for direct interactions between invaders and natives. For example, low abundance of invasive plants can affect a native plant community via competition for space, soil resources and light (Crooks 2005). Accordingly, we found a negative, linear relationship between goldenrod cover and native plant species richness.

However, the expectation for indirect relationships, such as recorded in pollinating insects, is not so obvious (Lenda et al. 2010). Indeed, we showed that the negative impact of invasive goldenrod cover on bee and butterfly communities is non-linear. This nonlinear response creates an threshold point and indicates that the invader effects accelerate only after a certain density threshold value is reached. We propose at least two food-web based mechanisms behind the effect of invasive plants resulting in the observed nonlinear impact. The first possible mechanism arises from the buffering potential of the environment such as food-web redundancy (Gilbert and Levine 2013). The second mechanism might be a result of the neutral or positive impact of the invaders on pollinators by increasing food-base (Hejda et al. 2009; Stout and Morales 2009). Both mechanisms may lead to a delayed abrupt collapse of populations (Kajzer-Bonk et al. 2016) or, alternatively, even reverse the negative impact of invasive plants on native pollinators. For example, patches with moderate cover of goldenrods can still provide sufficient key resources to maintain the lifecycle of native insects (Stout and Morales 2009). Pollinating insects, depending on their specialisation, may also switch between different plant species to find food and nesting sites. If flowering, the invasive plant can itself be an important food base for many pollinators (Bjerknes et al. 2007). We found a strong negative linear impact of goldenrod cover on the richness of native plant species, and a non-linear impact on pollinators. Thus, the buffering effect of the food-web might be a result of the food base redundancy of pollinators. Moreover, invasive goldenrods can be used as a food source by only some bee and butterfly species (Skórka et al. 2007; Lenda et al. 2010).

Butterflies appear to be least resistant to the invasion, there was a negative effect on the number of individuals at sites with 30-40\% goldenrod cover. Butterflies are herbivorous insects depending on different plant species during consecutive life stages. 

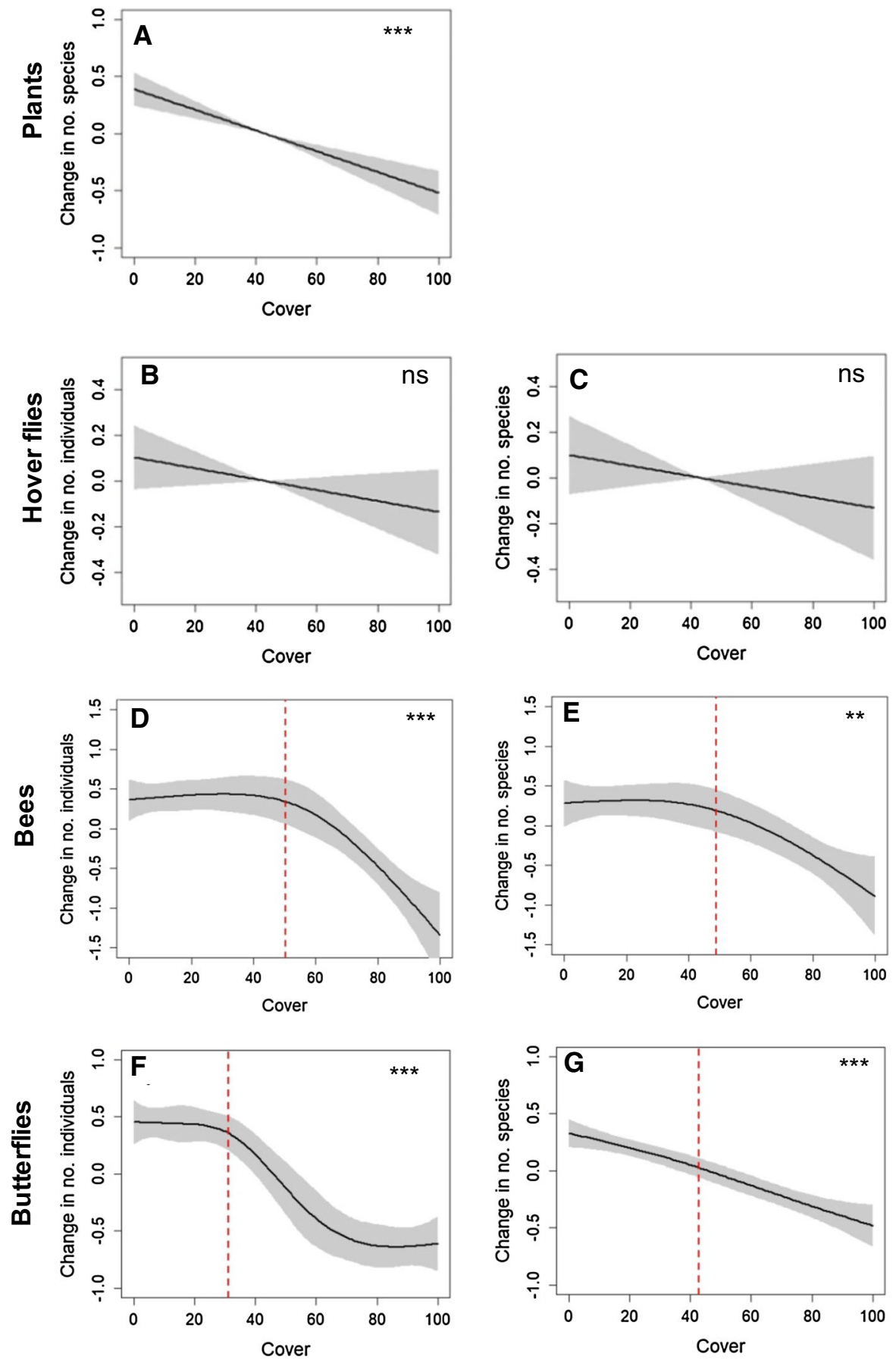

Fig. 3 The effects of invasive goldenrod cover on the native plant richness (a) as well as on hover fly $(\mathbf{b}, \mathbf{c})$, bee $(\mathbf{d}, \mathbf{e})$ and butterfly (f, $\mathbf{g})$ abundance and species richness as predicted by GAMM models presented in Table 1 . ns $p>0.05$, ${ }^{* *} p<0.01$,

$* * * p<0.001,95 \% \mathrm{CI}$ are marked with grey polygons. Red lines indicate estimated threshold points for non-linear relationships

As adults, they feed on nectar of plants that may be different than plant species used by their often species are recognised as food specialists for which food source redundancy is relatively low $-70 \%$ of collected species were food specialised. Thus, bearing 
Table 2 Generalised additive mixed models indicate the effect of goldenrod cover (smooth term) on the abundance and richness of pollinators and species richness of native plants

\begin{tabular}{lcccc}
\hline Variable & edf $^{\mathrm{a}}$ & $F$ Value & $p$ Value $^{\mathrm{b}}$ & $\mathrm{R}_{\text {adj }}^{2}$ \\
\hline Abundance & & & & \\
Bees & 2.711 & 13.27 & $<\mathbf{0 . 0 0 1}$ & 0.54 \\
Butterflies & 3.258 & 25.93 & $<\mathbf{0 . 0 0 1}$ & 0.93 \\
Hover flies & 1.000 & 2.160 & 0.156 & 0.29 \\
Species richness & & & & \\
Native plants & 1.000 & 29.07 & $<\mathbf{0 . 0 0 1}$ & 0.69 \\
Bees & 2.090 & 7.69 & $\mathbf{0 . 0 0 2}$ & 0.43 \\
Butterflies & 1.481 & 29.49 & $<\mathbf{0 . 0 0 1}$ & 0.58 \\
Hover flies & 1.000 & 1.358 & 0.254 & 0.05 \\
\hline
\end{tabular}

${ }^{a}$ Estimated degrees of freedom (edf $=1$ is a linear relationship); ${ }^{\mathrm{b}}$ Statistically significant $(p<0.05)$ effects are in bold

in mind the negative impact of goldenrods on native plants, and the dependency of butterfly life stages on different plant species, the impact of the invasive goldenrods on butterflies may multiply, leading to coextinction of host and butterfly (Koh 2004). Moreover, whereas some butterfly species adults can use invasive goldenrods as a nectar source, it seems that goldenrods are not used as food sources by their larvae (Ebert 2005; Buszko and Masłowski 2015). As such, the buffering mechanism seems to work only partially for butterflies, causing their relatively fast response to the invasion.

Among other pollinators, bees have the closest, very often mutual, relationships with native flowering plants, as both larvae and adult bees are dependent on nectar and pollen collected from flowers (Brock 2015). Compared to butterflies, the number of bee species and individuals appeared to show a strong non-linear impact to goldenrod invasion. This relative robustness might indicate the strong food base redundancy of bees, as only $35 \%$ of collected bee species were food specialised. The negative impact at the level of 50\% goldenrod cover may also indicate that bees utilise goldenrods, but as a supplementary resource rather than one complementary to the non-invaded meadows (Moroń et al. 2019). Moreover, for some foodspecialised bees, a patch dominated by one flowering species might be not preferred (Moroń et al. 2009).

Hover flies, among all the studied pollinator groups, are the least flower specialised because both adults and larvae feed on nectar and pollen as well as on other food sources (Brock 2015). However, the larvae of some species can be specialised, for example by requiring decaying wood to complete their lifecycle, or in the case of predators feeding on aphids (Brock 2015). Unlike bees and butterflies, which often have mutual relationships with a particular group of plants (Brock 2015), hover flies seems to be capable of using flowers of many species as food sources. The ability to use available resources might give an advantage, especially in habitats homogenised by few food sources. This may explain why, for hover flies, we found no direct link between the number of species and individuals, and goldenrod cover.

The pollinator and plant community assemblages seem to be affected as goldenrod cover increases. Changes in the community assemblages are a result of species loss rather than of the constitution of new communities by species replacement. Thus, in areas highly impacted by invasive goldenrods, only a part of the original pool of species can persist. The next step should be to identify traits which make some species less vulnerable to biological invasions.

Global environmental changes, along with the pressure of invasive species, has prompted a need to understand the trajectories of complex ecological systems (Mouquet et al. 2015) for better projections of biodiversity loss or changes and ecosystem functioning on the global scale (Barnosky et al. 2012). Unfortunately, biological invasions seem to be idiosyncratic, including non-linear relationships between invaders and natives, which makes prediction much harder (Richardson et al. 2000). However, if non-linear relationships are results of the understood intrinsic processes, the relationships can be incorporated into ecological predictions and plant management (Crooks 2005). The existence of the non-linear relationships also indicate some resistance of native communities to invasion, at least until the invasive species reaches a certain density. This prompts the recommendation that goldenrod cover below $30 \%$ for butterflies and about $50 \%$ for bees should sustain pollinator populations and their ecosystem services in meadow habitats under pressure of alien goldenrods. It also indicates that habitats and their pollinator communities, even when invaded, can be successfully restored to the point of relatively moderate goldenrod density, lowering costs of invader removal and the reintroduction of native species (Szymura et al. 2016). 
Acknowledgements The referees provided very useful critical comments on the manuscript.

Open Access This article is distributed under the terms of the Creative Commons Attribution 4.0 International License (http:// creativecommons.org/licenses/by/4.0/), which permits unrestricted use, distribution, and reproduction in any medium, provided you give appropriate credit to the original author(s) and the source, provide a link to the Creative Commons license, and indicate if changes were made.

\section{Appendix 1}

The effects of invasive goldenrod cover on the bee, butterfly and hoverfly abundance during pre-flowering and flowering period of invasive goldenrods as
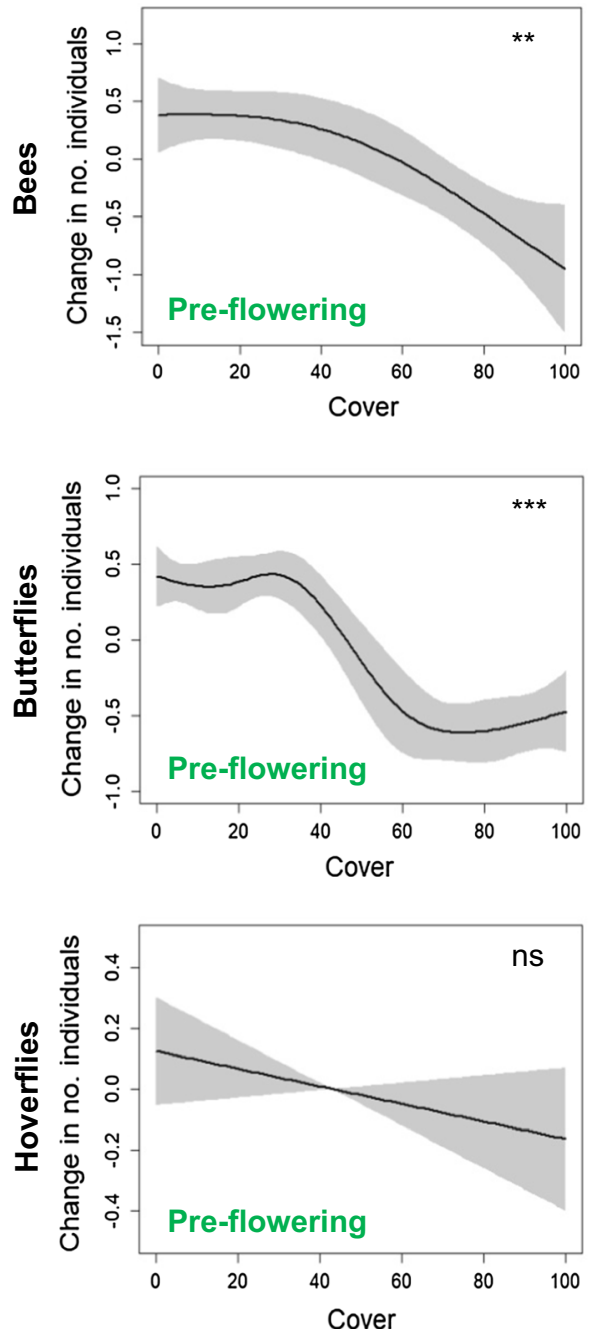

predicted by GAMM models. ns $p>0.05$; $* p<0.05, * * p<0.01$, *** $p<0.001,95 \%$ CI are marked with grey polygons.

\section{Appendix 2}

The effects of invasive goldenrod cover on the native forb and graminoid species richness as predicted by GAMM models. ns $p>0.05 ; * p<0.05$, ** $p<0.01$, $* * * p<0.001,95 \%$ CI are marked with grey polygons.
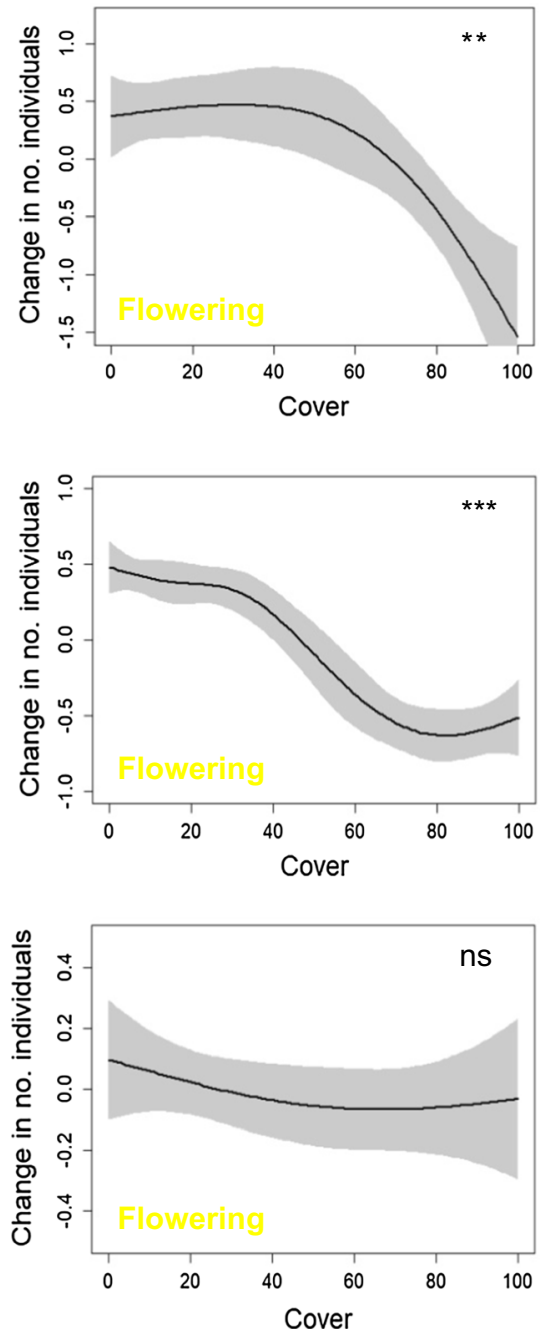

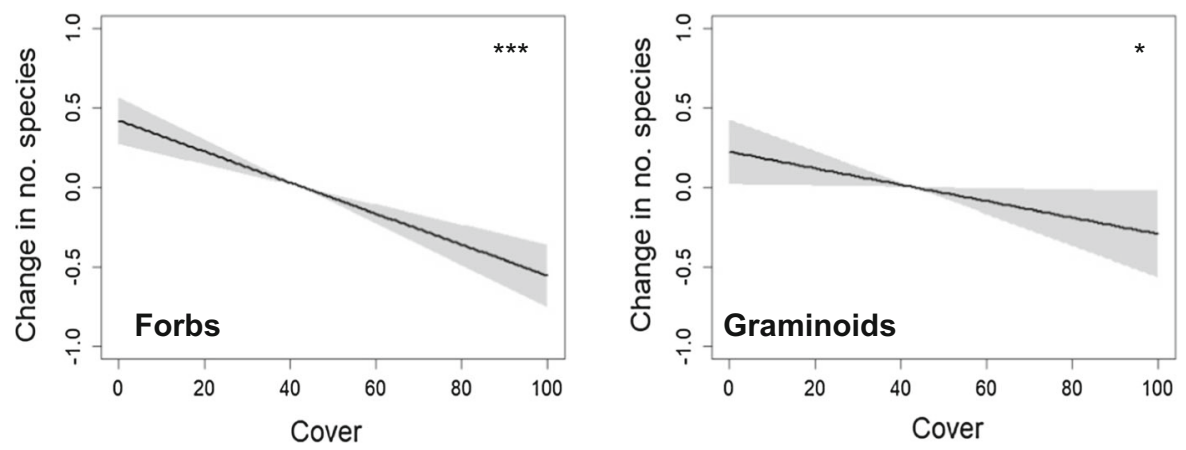

\section{Appendix 3}

List of pollinator and flowering plant species found at study sites.

\begin{tabular}{|c|c|c|c|}
\hline Bees & Butterflies & Hover flies & Plants \\
\hline Andrena chrysosceles & Aglais urticae & Anasymia lineata & Achillea millefolium \\
\hline Andrena denticulata & Apatura ilia & Cheilosia pagana & Aegopodium podagraria \\
\hline Andrena hattorfiana & Apatura iris & Cheilosia proxima & Alopecurus pratensis \\
\hline Andrena labiata & Aphantopus hyperanthus & Cheilosia vernalis & Armoracia rusticana \\
\hline Andrena minutula & Araschnia levana & Chrysotoxum bicinctum & Artemisia vulgaris \\
\hline Andrena minutuloides & Argynnis aglaja & Chrysotoxum festivum & Astragalus glycyphyllos \\
\hline Andrena pontica & Argynnis paphia & Episyrphus balteatus & Atriplex nitens \\
\hline Andrena proxima & Aricia agestis & Eristalinus aeneus & Bromus arvensis \\
\hline Andrena subopaca & Boloria dia & Eristalinus sepulchralis & Calamagrostis epigeios \\
\hline Bombus lapidarius & Boloria selene & Eristalis arbustorum & Carduus crispus \\
\hline Bombus pascuorum & Brenthis ino & Eristalis nemorum & Centaurea jacea \\
\hline Bombus pratorum & Callophrys rubi & Eristalis pertinax & Centaurea scabiosa \\
\hline Bombus sylvarum & Carcharodus alceae & Eristalis tenax & Chamaenerion angustifolium \\
\hline Bombus terrestris & Celastrina argiolus & Eupeodes latifasciatus & Chamomilla recutia \\
\hline Colletes daviesanus & Coenonympha arcania & Eupeodes luniger & Cirsium arvense \\
\hline Colletes fodiens & Coenonympha glycerion & Helophilus hybridus & Cirsium oleraceum \\
\hline Colletes similis & Coenonympha pamphilus & Helophilus pendulus & Convolvulus arvensis \\
\hline Dasypoda altercator & Colias hyale & Helophilus trivittatus & Crataegus monogyna \\
\hline Epeoloides coecutiens & Cupido argiades & Melangyna compositarum & Dactylis glomerata \\
\hline Evylaeus albipes & Erynnis tages & Melanostoma mellinum & Daucus carota \\
\hline Evylaeus calceatus & Gonepteryx rhamni & Meligramma triangulifera & Elymus repens \\
\hline Evylaeus fulvicornis & Hesperia comma & Merodon equestris & Epilobium hirsutum \\
\hline Evylaeus laticeps & Inachis io & Microdon mutabilis & Equisetum arvense \\
\hline Evylaeus leucopus & Issoria lathonia & Parhelophilus versicolor & Erigeron anпииs \\
\hline Evylaeus morio & Leptidea sp. & Pipizella viduata & Erysimum cheiranthoides \\
\hline Evylaeus pauxillus & Lycaena dispar & Platycheirus angustatus & Euphorbia cyparissias \\
\hline Evylaeus sabulosus & Lycaena hippothoe & Platycheirus clypeatus & Festuca pratensis \\
\hline Heriades truncorum & Lycaena phlaeas & Platycheirus fulviventris & Filipendula ulmaria \\
\hline
\end{tabular}


continued

\begin{tabular}{|c|c|c|c|}
\hline Bees & Butterflies & Hover flies & Plants \\
\hline Hoplitis leucomelana & Lycaena tityrus & Platycheirus immarginatus & Fragaria vesca \\
\hline Hoplitis spinulosa & Lycaena virgaureae & Platycheirus occultus & Galium verum \\
\hline Hylaeus difformis & Maniola jurtina & Platycheirus peltatus & Gentiana pneumonanthe \\
\hline Hylaeus gredleri & Minois dryas & Platycheirus scutatus & Geranium pratense \\
\hline Hylaeus sinuatus & Ochlodes sylvanus & Sphaerophoria scripta & Geum urbanum \\
\hline Macropis europaea & Papilio machaon & Sphaerophoria taeniata & Heracleum sphondylium \\
\hline Macropis fulvipes & Phengaris alcon & Syritta pipiens & Holcus lanatus \\
\hline Megachile alpicola & Phengaris nausithous & Syrphus ribessi & Hypericum perforatum \\
\hline Melitta nigricans & Phengaris teleius & Syrphus torvus & Iris sibirica \\
\hline Seladonia subaurata & Pieris brassicae & Triglyphus primus & Lamium amplexicaule \\
\hline Seladonia tumulorum & Pieris napi & Tropidia scita & Lathyrus pratensis \\
\hline \multirow[t]{34}{*}{ Sphecodes crassus } & Pieris rapae & Xanthandrus comtus & Lathyrus tuberosus \\
\hline & Plebejus argus & Xanthogramma pedissequum & Leucanthemum vulgare \\
\hline & Plebejus argyrognomon & Xylota segnis & Lolium perenne \\
\hline & Polygonia c-album & & Lychnis flos-cuculi \\
\hline & Polyommatus icarus & & Lysimachia vulgaris \\
\hline & Polyommatus semiargus & & Lythrum salicaria \\
\hline & Pontia edusa & & Medicago lupulina \\
\hline & Pyrgus alveus & & Melilotus alba \\
\hline & Pyrgus malvae & & Mentha arvensis \\
\hline & Thecla betulae & & Molinia caerulea \\
\hline & Thymelicus lineola & & Origanum vulgare \\
\hline & Thymelicus sylvestris & & Phleum pratense \\
\hline & Vanessa atalanta & & Phragmites australis \\
\hline & Vanessa cardui & & Plantago lanceolata \\
\hline & & & Plantago major \\
\hline & & & Роа аппиа \\
\hline & & & Poa pratensis \\
\hline & & & Polygonum bistorta \\
\hline & & & Potentilla anserina \\
\hline & & & Potentilla erecta \\
\hline & & & Ranunculus acris \\
\hline & & & Reseda lutea \\
\hline & & & Rosa canina \\
\hline & & & Rubus caesius \\
\hline & & & Rubus idaeus \\
\hline & & & Rumex acetosa \\
\hline & & & Sanguisorba officinalis \\
\hline & & & Solidago canadensis \\
\hline & & & Solidago gigantea \\
\hline & & & Stellaria media \\
\hline & & & Symphytum officinale \\
\hline & & & Tanacetum vulgare \\
\hline & & & Taraxacum officinale \\
\hline & & & Trifolium hybridum \\
\hline
\end{tabular}


continued

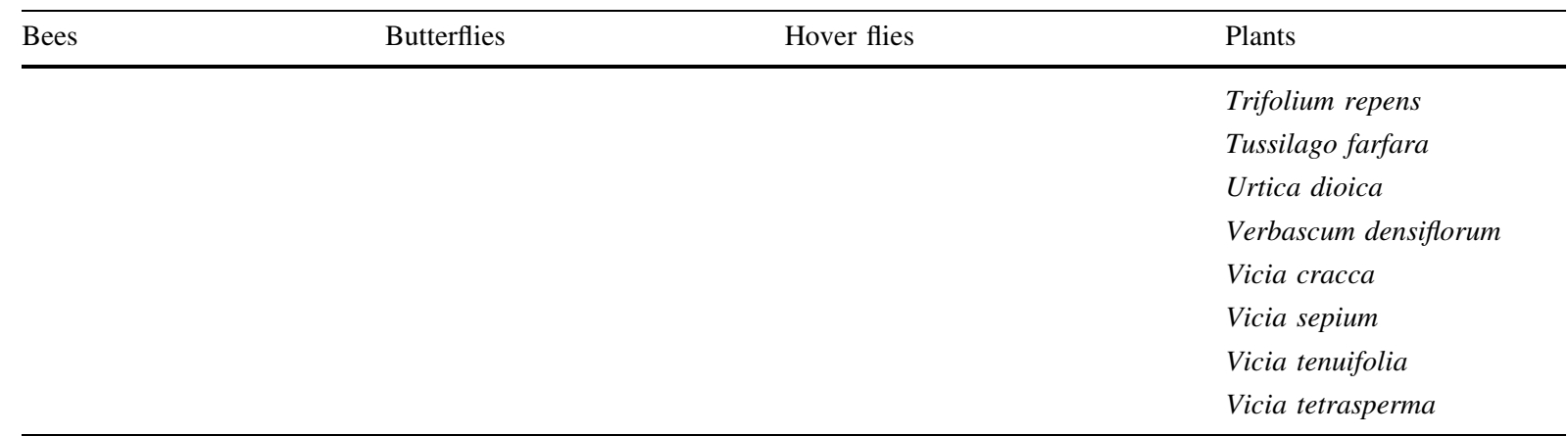

\section{References}

Amano T, Coverdale R, Peh KSH (2016) The importance of globalisation in driving the introduction and establishment of alien species in Europe. Ecography (Cop) 39:1118-1128. https://doi.org/10.1111/ecog.01893

Baranová B, Manko P, Jászay T (2014) Differences in surfacedwelling beetles of grasslands invaded and non-invaded by goldenrods (Solidago canadensis, S. gigantea) with special reference to Carabidae. J Insect Conserv 18:623-635. https://doi.org/10.1007/s10841-014-9666-0

Barnosky AD, Hadly EA, Bascompte J et al (2012) Approaching a state shift in Earth's biosphere. Nature 486:52-58. https:// doi.org/10.1038/nature11018

Baselga A (2012) The relationship between species replacement, dissimilarity derived from nestedness, and nestedness. Glob Ecol Biogeogr 21:1223-1232. https://doi.org/ 10.1111/j.1466-8238.2011.00756.x

Baselga A, Orme CDL (2012) betapart: an R package for the study of beta diversity. Methods Ecol Evol 3:808-812. https://doi.org/10.1111/j.2041-210X.2012.00224.x

Baselga A, Orme D, Villeger S, Bortoli J De (2013) Package "betapart"

Bjerknes A-L, Totland O, Hegland SJ, Nielsen A (2007) Do alien plant invasions really affect pollination success in native plant species? Biol Conserv 138:1-12. https://doi. org/10.1016/j.biocon.2007.04.015

Blaauw BR, Isaacs R (2014) Larger patches of diverse floral resources increase insect pollinator density, diversity, and their pollination of native wildflowers. Basic Appl Ecol 15:701-711. https://doi.org/10.1016/j.baae.2014.10.001

Brock PD (2015) A comprehensive guide to insects of Britain and Ireland. Pisces Publications, Newbury

Buszko J, Masłowski J (2015) Motyle dzienne Polski. Koliber \& Jarosław Buszko, Janusz Masłowski, Nowy Sacz

Crooks JA (2005) Lag times and exotic species: the ecology and management of biological invasions in slow-motion1. Écoscience 12:316-329. https://doi.org/10.2980/i11956860-12-3-316.1

de Groot M, Kleijn D, Jogan N (2007) Species groups occupying different trophic levels respond differently to the invasion of semi-natural vegetation by Solidago canadensis. Biol Conserv 136:612-617. https://doi.org/10.1016/j.biocon. 2007.01.005
Development Core Team R (2016) R: a language and environment for statistical computing. R Foundation for Statistical Computing, Vienna

Dubiel E (1995) Kierunki antropogenicznych przemian szaty roślinnej doliny Wisły w Krakowie. Folia Geogr Ser Geogr 26-27:139-148

Dupont YL, Padrón B, Olesen JM, Petanidou T (2009) Spatiotemporal variation in the structure of pollination networks. Oikos 118:1261-1269. https://doi.org/10.1111/j.16000706.2009.17594.x

Ebert G (ed) (2005) Die Schmetterlinge Baden-Wurttembergs. Band 10, Erganzungsband. Eugen Ulmer, Stuttgart

Elgersma KJ, Ehrenfeld JG (2011) Linear and non-linear impacts of a non-native plant invasion on soil microbial community structure and function. Biol Invasions 13:757-768. https://doi.org/10.1007/s10530-010-9866-9

Fenesi A, Vágási CI, Beldean M et al (2015) Solidago canadensis impacts on native plant and pollinator communities in different-aged old fields. Basic Appl Ecol 16:335-346. https://doi.org/10.1016/j.baae.2015.03.003

Gilbert B, Levine JM (2013) Plant invasions and extinction debts. Proc Natl Acad Sci 110:1744-1749. https://doi.org/ 10.1073/pnas. 1212375110

Haddad NM, Crutsinger GM, Gross K et al (2009) Plant species loss decreases arthropod diversity and shifts trophic structure. Ecol Lett 12:1029-1039. https://doi.org/10. 1111/j.1461-0248.2009.01356.x

Hejda M, Pyšek P (2006) What is the impact of impatiens glandulifera on species diversity of invaded riparian vegetation? Biol Conserv 132:143-152. https://doi.org/10. 1016/j.biocon.2006.03.025

Hejda M, Pyšek P, Jarošík V (2009) Impact of invasive plants on the species richness, diversity and composition of invaded communities. J Ecol 97:393-403. https://doi.org/10.1111/j. 1365-2745.2009.01480.x

Hulme PE, Pyšek P, Jarošík V et al (2012) Bias and error in understanding plant invasion impacts. Trends Ecol Evol 28:212-218. https://doi.org/10.1016/j.tree.2012.10.010

Kabuce N (2006) NOBANIS - invasive alien species fact sheet Solidago canadensis. NOBANIS-invasive alien species fact sheet

Kajzer-Bonk J, Szpiłyk D, Woyciechowski M (2016) Invasive goldenrods affect abundance and diversity of grassland ant communities (Hymenoptera: Formicidae). J Insect 
Conserv 20:99-105. https://doi.org/10.1007/s10841-0169843-4

Koh LP (2004) Species coextinctions and the biodiversity crisis. Science 305:1632-1634. https://doi.org/10.1126/science. 1101101

Kornaś J, Medwecka-Kornaś A (1974) Szata roślinna Krakowa

Lenda M, Skórka P, Moroń D (2010) Invasive alien plant species-A threat or an opportunity for pollinating insects in agricultural landscapes? In: Lee TH (ed) Agricultural economics: new research. Nova Science Publishers, New York, pp 67-87

Lenda M, Witek M, Skorka P, Moroń D (2013) Invasive alien plants affect grassland ant communities, colony size and foraging behaviour. Biol Invasions 15:2403-2414. https:// doi.org/10.1007/s10530-013-0461-8

Lenda M, Knops JH, Skórka P et al (2018) Cascading effects of changes in land use on the invasion of the walnut Juglans regia in forest ecosystems. J Ecol 106:671-686. https://doi. org/10.1111/1365-2745.12827

McCary MA, Mores R, Farfan MA, Wise DH (2016) Invasive plants have different effects on trophic structure of green and brown food webs in terrestrial ecosystems: a metaanalysis. Ecol Lett. https://doi.org/10.1111/ele.12562

Memmott J, Alonso D, Berlow EL et al (2006) Biodiversity loss and ecological network structure. In: Pascual M, Dunne JA (eds) Ecological networks: linking structure to dynamics in food webs. Oxford University Press, Oxford, pp 325-350

Moroń D, Szentgyörgyi H, Wantuch M et al (2008) Diversity of wild bees in wet meadows: implication for conservation. Wetlands 28:975-983

Moroń D, Lenda M, Skórka P et al (2009) Wild pollinator communities are negatively affected by invasion of alien goldenrods in grassland landscapes. Biol Conserv 142:1322-1332. https://doi.org/10.1016/j.biocon.2008.12. 036

Moroń D, Skórka P, Lenda M (2019) Disappearing edge: the flowering period changes the distribution of insect pollinators in invasive goldenrod patches. Insect Conserv Divers. https://doi.org/10.1111/icad.12305

Mouquet N, Gravel D, Massol F, Calcagno V (2012) Extending the concept of keystone species to communities and ecosystems. Ecol Lett. https://doi.org/10.1111/ele.12014

Mouquet N, Lagadeuc Y, Devictor V et al (2015) REVIEW: predictive ecology in a changing world. J Appl Ecol 52:1293-1310. https://doi.org/10.1111/1365-2664.12482

Muggeo VMR (2015) Regression models with breakpoints/ changepoints estimation. $\mathrm{R}$ package version 0.5-1.4

Oskanen J, Blanchet FG, Kindt R et al (2013) Vegan: community ecology package. $\mathrm{R}$ package version $2.0-10$

Pal RW, Chen S, Nagy DU, Callaway RM (2015) Impacts of Solidago gigantea on other species at home and away. Biol Invasions 17:3317-3325. https://doi.org/10.1007/s10530015-0955-7

Panetta F, Gooden B (2017) Managing for biodiversity: impact and action thresholds for invasive plants in natural ecosystems. NeoBiota 34:53-66. https://doi.org/10.3897/ neobiota.34.11821

Pavek PLS (2012) Plant fact sheet for Canada goldenrod (Solidago canadensis). In: USDA-Natural Resources Conservation Service. https://plants.usda.gov/factsheet/pdf/fs_ soca6.pdf
Pawson SM, McCarthy JK, Ledgard NJ, Didham RK (2010) Density-dependent impacts of exotic conifer invasion on grassland invertebrate assemblages. J Appl Ecol 47:1053-1062. https://doi.org/10.1111/j.1365-2664.2010. 01855.x

Pejchar L, Mooney HA (2009) Invasive species, ecosystem services and human well-being. Trends Ecol Evol 24:497-504. https://doi.org/10.1016/j.tree.2009.03.016

Pępkowska A (2002) Inwentaryzacja i waloryzacja krajobrazowo-przyrodnicza terenów przyległych do Kampusu 600-lecia Odnowienia Uiwersytetu Jagiellońskiego. Jagiellonian University, Kraków

Pollard E, Yates TJ (1993) Monitoring butterflies for ecology and conservation. Chapman \& Hall, London

Pyšek P, Jarošík V, Hulme PE et al (2012) A global assessment of invasive plant impacts on resident species, communities and ecosystems: the interaction of impact measures, invading species' traits and environment. Glob Change Biol 18:1725-1737. https://doi.org/10.1111/j.1365-2486. 2011.02636.x

QGIS Development Team (2018) QGIS geographic information system. Open source geospatial foundation project. https:// qgis.org/en/site/. Accessed 5 June 2018

Richardson DM, Allsopp N, D'antonio CM et al (2000) Plant invasions - the role of mutualisms. Biol Rev 75:65-93. https://doi.org/10.1111/j.1469-185X.1999.tb00041.x

Richardson DM, Holmes PM, Esler KJ et al (2007) Riparian vegetation: degradation, alien plant invasions, and restoration prospects RID A-1495-2008 RID F-5883-2010. Divers Distrib 13:126-139. https://doi.org/10.1111/j.14724642.2006.00314.x

Salisbury A, Armitage J, Bostock H et al (2015) EDITOR'S CHOICE: enhancing gardens as habitats for flower-visiting aerial insects (pollinators): Should we plant native or exotic species? J Appl Ecol 52:1156-1164. https://doi.org/10. 1111/1365-2664.12499

Simao MCM, Flory SL, Rudgers JA (2010) Experimental plant invasion reduces arthropod abundance and richness across multiple trophic levels. Oikos 119:1553-1562. https://doi. org/10.1111/j.1600-0706.2010.18382.x

Skórka P, Settele J, Woyciechowski M (2007) Effects of management cessation on grassland butterflies in southern Poland. Agric Ecosyst Environ 121:319-324. https://doi. org/10.1016/j.agee.2006.11.001

Skórka P, Lenda M, Tryjanowski P (2010) Invasive alien goldenrods negatively affect grassland bird communities in Eastern Europe. Biol Conserv 143:856-861. https://doi. org/10.1016/j.biocon.2009.12.030

Stout JC, Morales CL (2009) Ecological impacts of invasive alien species on bees. Apidologie 40:388-409. https://doi. org/10.1051/apido/2009023

Szymura M, Szymura TH, Wolski K (2016) Invasive solidago species: How large area do they occupy and what would be the cost of their removal? Polish J Ecol 64:25-34. https:// doi.org/10.3161/15052249PJE2016.64.1.003

Tepedino VJ, Bradley BA, Griswold TL (2008) Might flowers of invasive plants increase native bee carrying capacity? Intimations from Capitol Reef National Park, Utah. Nat Areas J 28:44-50. https://doi.org/10.3375/08858608(2008)28\%5b44:MFOIPI\%5d2.0.CO;2 
van der Putten WH, Bardgett RD, Bever JD et al (2013) Plantsoil feedbacks: the past, the present and future challenges. J Ecol 101:265-276. https://doi.org/10.1111/1365-2745. 12054

Weber E (2001) Current and potential ranges of three exotic goldenrods (Solidago) in Europe. Conserv Biol 15:122-128

Westphal C, Bommarco R, Carré G et al (2008) Measuring bee diversity in different European habitats and biogeographical regions. Ecol Monogr 78:653-671. https://doi.org/10.1890/07-1292.1

Wood SN (2006) Generalized additive models: an introduction with R. Chapman and Hall, Boca Raton

Yokomizo H, Possingham HP, Thomas MB, Buckley YM (2009) Managing the impact of invasive species: the value of knowing the density-impact curve. Ecol Appl 19:376-386. https://doi.org/10.1890/08-0442.1 